\title{
ARTIGO \\ O Estado de Coisas Inconstitucional como estratégia de diálogo institucional no julgamento da ADPF 347 MC/DF pelo Supremo Tribunal Federal ${ }^{1}$
}

\author{
Martin Magnus Petiz ${ }^{2}$
}

Como citar este artigo: PETIZ, Martin Magnus. O Estado de Coisas Insconstitucional como estratégia de diálogo institucional no julgamento da ADPF 347 MC/DF pelo Supremo Tribunal Federal. Revista de Ciências do Estado. Belo Horizonte: v. 6, n. 1, e26989. ISSN: 2525-8036.

Resumo: O trabalho analisa a capacidade do Estado de Coisas Inconstitucional (ECI) de servir como estratégia de diálogo institucional no Supremo Tribunal Federal em julgamentos de litígios em que é necessário mobilizar diversos atores para se alcançar um objetivo constitucional. Para tanto, o trabalho possui o aspecto normativo de desenvolver o diálogo institucional como modelo de separação de poderes, estrutura na qual os poderes interagem entre si na busca pelo melhor sentido constitucional, o que teria um potencial epistêmico de suprir omissões inconstitucionais. Num segundo momento, será apresentado o ECI como técnica decisória, mediante revisão bibliográfica e análise jurisprudencial qualitativa de julgados paradigmáticos da Corte Constitucional Colombiana, procurando-se apresentar argumentos analíticos sobre as possibilidades e limites do instituto dentro da estrutura de separação de poderes apresentada, para, então, analisar como STF procedeu na ADPF 347 MC. O trabalho conclui que a aplicação ideal do ECI, com maior efetividade em um sentido tanto material quanto simbólico, se dá por meio de uma decisão que envolva o seu rastreamento pelo Tribunal, com a participação de atores sociais e políticos na formulação das políticas públicas, o que não foi efetivado até o momento na ADPF 347, demandando que o Supremo revisite logo o tema em julgamento de mérito.

Palavras-chave: Estado de Coisas Inconstitucional; jurisdição constitucional; separação de poderes; diálogo institucional; ADPF 347 MC.

Recebido em 05.01.2021

Aprovado em 26.03.2021

Publicado em 05.04.2021

\footnotetext{
${ }^{1}$ Pesquisa financiada pela Fundação de Amparo à Pesquisa do Estado do Rio Grande do Sul - FAPERGS.

${ }^{2}$ Graduando do $9^{\circ}$ semestre em Ciências Jurídicas e Sociais - Direito na Universidade Federal do Rio Grande do Sul - URRGS. Bolsista de iniciação científica PROBIC - FAPERGS UFRGS no Projeto de Pesquisa "Por que uma sociologia histórico-constitucional para a América Latina?", sob orientação da Profa. Dra. Roberta Camineiro Baggio. Estagiário no Escritório de Advocacia Paese, Fereira \& Advogados Associados.
} 


\section{INTRODUÇÃO}

O acionamento da jurisdição constitucional para tomadas de posição acerca de questões envolvendo políticas públicas é tema comum nos dias de hoje. As análises do tema variam entre visões otimistas sobre o papel das Cortes Constitucionais como a "última trincheira do cidadão" na garantia dos seus direitos, até entendimentos de que a sua interferência desmedida nos assuntos das comunidades políticas vem enfraquecendo o exercício da cidadania e da própria política. Nada obstante, as omissões estatais existem e, diante da complexidade das exigências sociais que tomam forma em nossa sociedade, em muitos casos o Poder Judiciário tem se encontrado em face de violações de direitos fundamentais decorrentes da inércia dos demais poderes e órgãos responsáveis. Em face disso, a Corte Constitucional Colombiana (CCC) criou o instituto do Estado de Coisas Inconstitucional (ECI), declarando-o já em diversos casos de violação reiterada de direitos por conta de omissão estatal, o que o Supremo Tribunal Federal pode vir a reproduzir quando do julgamento do mérito da ADPF 347/DF.

Assim, a questão reside em se analisar se o instituto do ECI pode servir como técnica de resolução de litígios estruturais de modo legítimo dentro da estrutura da separação de poderes, ao mesmo tempo em que mantendo a sua qualidade de instrumento capaz de concretizar direitos sociais quando estes são negligenciados sistematicamente pelos demais poderes eleitos. Isso porque não se pode ignorar a pertinência das críticas direcionadas à supremacia judicial, tendo em vista as Cortes Constitucionais possuírem a credencial democrática mais fraca dentre os poderes, bem como à sua reduzida noção sobre o impacto das suas decisões num horizonte próximo. De modo subsidiário, ante a timidez das medidas aprovadas pelo Supremo em sede de Medida Cautelar na referida ação, pretende-se averiguar se é possível chamar a decisão de declaratória de um ECI, como a literatura brasileira tende a afirmar, ao mesmo tempo que perquirindo os seus efeitos concretos.

Diante disso, o presente trabalho busca conjugar argumentos normativos e analíticos, adotando como hipótese a possibilidade de uma aplicação do ECI como estratégia de diálogo institucional. O diálogo institucional é tido como uma concepção específica de separação de poderes, no sentido de que os problemas constitucionais podem e devem ser resolvidos num processo de interação entre os poderes, órgãos e demais atores políticos envolvidos. Trata-se de uma perspectiva fluida da separação de poderes - isto é, sem apego a um modelo estanque 
e rígido de competências - e baseada numa ideia de legitimidade política, em que, diante das diversas demandas envolvendo a Constituição, os poderes podem cooperar e se complementar na função e efetivar os comandos constitucionais.

A metodologia adotada envolve, em primeiro lugar, uma revisão bibliográfica das diferentes perspectivas sobre o papel do Poder Judiciário na divisão de poderes contemporânea, apresentando-se o diálogo institucional como modelo normativo de separação de poderes. sendo o conceito de legitimidade política a palavra chave para definir a interferência das Cortes nas políticas públicas. Numa segunda parte, se procederá na formulação de um tipo ideal do ECI. Para cumprir esse desiderato, revisar-se-á a bibliografia pertinente a respeito dos debates envolvendo a aplicação do ECI no Brasil pelo Supremo, ao lado da análise de duas decisões paradigmáticas da $\mathrm{CCC}$, as quais receberam análise mais detida da literatura, mormente a pesquisa de Rodríguez-Garavito, tanto sozinho (2011), quanto em conjunto com Diana Rodríguez-Franco (2015). Desse modo, busca-se identificar as possibilidades de uma aplicação dialógica do ECI como técnica decisória efetiva e legítima, identificando-se, no julgamento liminar do STF na ADPF 347/DF, uma argumentação inicial coerente com o tipo ideal, uma vez que conjugou o argumento de inércia estatal e de subrepresentação de minorias no caso concreto. No entanto, se defenderá que os efeitos concretos e simbólicos da decisão acabaram sendo irrisórios, sendo difícil enquadrá-la no conceito de ECI. Com isso, propõe-se um tipo ideal do ECI a ser aplicado pelo STF, defendendo-se que o mérito da ADPF 347/DF seja revisitada de modo urgente, com o Supremo mantendo, desta vez, o poder de rastrear a efetivação da decisão declaratória do ECI, para, assim, utilizar das potencialidades do diálogo institucional para tornar a sua intervenção mais adequada e efetiva.

\section{O PROBLEMA DA ÚlTIMA PALAVRA ABSOLUTA: SUPREMACIA} JUDICIAL E DIVERGÊNCIA SOBRE DIREITOS

O Estado de Coisas Inconstitucional (ECI) constitui uma técnica de tutela de direitos para resolução de litígios estruturais (RODRÍGUEZ-GARAVITO; RODRÍGUEZ-FRANCO, 2015, p. 64-65), tendo sido desenvolvido e aplicado pela primeira vez pela Corte Constitucional Colombiana (CCC) como resposta a violações sistemáticas de direitos fundamentais. (COLÔMBIA, 1997). No Brasil, o instituto apareceu na ADPF n. 347/DF, ajuizada pelo Partido Socialismo e Liberdade (PSOL), com o fito de que fosse declarado o ECI no que diz respeito à situação do nosso sistema penitenciário. $\mathrm{Na}$ academia, tem sido adjetivado como sendo produto de uma postura progressista das Cortes Constitucionais, ao se 
buscar não só superar uma visão mais passiva do Judiciário na aplicação da Constituição, mas também por buscar conceder melhores condições de vida a grupos desprivilegiados. (ARIZA, p. 129-131). A despeito disso, existem fundadas críticas sobre a adoção de tal postura pelas Cortes, as quais não podem ser vistas apenas sobre o prisma político.

O receio de que o Supremo sub-rogue para si mais esse poder - o de rastrear o cumprimento de políticas públicas a partir de suas decisões - faz ressurgir o debate sobre os fenômenos do ativismo judicial e da judicialização da política. A literatura tradicional vê na passagem do Estado Legislativo para o Estado Constitucional a mudança de paradigma na atuação das cortes, o que, para alguns, teria imposto a supremacia judicial, com o controle de constitucionalidade. (BARROSO, 2012, p. 359). No Brasil (BARROSO, 2006, p. 23), assim como na Colômbia (YEPES, 2004, p. 546) e na maioria dos países da América Latina que passaram pelo movimento de constitucionalização ocorrido após a década de 1980 (AVRITZER, 2017, p. 27-37), a redemocratização ocorrida nos anos 1980-1990 instaurou uma Constituição com uma carta de direitos analítica, ao lado de amplos mecanismos de acionamento do Judiciário. Esse ambiente propiciou o surgimento da judicialização da política, fenômeno por meio do qual o Poder Judiciário passou a julgar cada vez mais questões morais, sociais e políticas. (BARROSO, 2012, p. 360). Seria a constatação de um fato, facilitado pela consagração de diversos direitos e regulamentações constitucionais de modo expresso. (TASSINARI, 2013, p. 32). ${ }^{3}$ Já a postura ativa que o Judiciário começou a tomar diante dessa questão é denominada de ativismo judicial. O juízo de valor dos autores sobre o tema varia, o que vem indicando, inclusive, uma certa perda de operacionalidade do mesmo: Luís Roberto Barroso (2012, p. 365) entende que o ativismo judicial envolve uma participação mais ampla e intensa do Judiciário na concretização dos valores e fins constitucionais; Patrício A. Maraniello (2012, p. 125) também possui uma visão favorável ao ativismo, entendendo que ele é toda atitude ativa, frontal e direta diante de obstáculos à persecução dos fins constitucionais; Clarissa Tassinari (2012, p. 37), por outra banda, de modo mais crítico, entende que o ativismo judicial se dá sempre quando o Judiciário toma uma decisão para além dos limites constitucionais.

Essa controvérsia envolve, ao fim e ao cabo, a questão maior sobre por que, afinal, deveríamos confiar a um corpo de onze juízes não eleitos a tarefa de decidir questões tão delicadas da nossa sociedade, pergunta posta por Jeremy Waldron (2006, p. 1391), crítico da

\footnotetext{
${ }^{3}$ Já existem posições em sentido diverso, no sentido de que a judicialização decorreria de um movimento de autoproteção das elites econômicas em meio a um cenário de ascensão das incertezas eleitorais, preferindo esses grupos transferir o poder de decisão sobre questões sensíveis da política para um corpo não eleito, também de elite (HIRSCHL, 2007, p. 41 e ss.).
} 
revisão judicial, para quem haveria, em resumo, quatro argumentos contrários ao instituto. Num primeiro momento, Waldron foca naqueles que seriam os seus argumentos substancialistas (outcome-related reasons), isto é, aponta porque considera o Judiciário menos habilitado do que o Legislativo para captar o "sentimento" do povo nas suas decisões. Nisso estaria, por exemplo, a crítica ao fato de que sempre há divergências interpretativas sobre os direitos e, sobretudo, morais sobre o significado e o alcance daqueles, ainda que positivados uma Constituição (WALDRON, 2006, p. 1377). O argumento mais importante de Waldron (2006, p. 1391), para os fins deste trabalho, reside na alegação de que o processo legislativo possuiria maior legitimidade democrática para resolver controvérsias sobre direitos, pois os juízes são eleitos apenas indiretamente. Esse é o seu argumento procedimental (processrelated reasons); é a ideia de que o processo de tomada de decisão do Legislativo tende a ser sempre mais democrático, levando em conta as opiniões de todos os representantes da melhor maneira.

Tais críticas são pertinentes. A noção de divergência sobre direitos em uma democracia é a sua própria razão de ser. E mais: é irrealista, e até mesmo hostil, entender que nossas diferenças enquanto cidadãos são fundadas na ignorância, na perversidade ou nas rivalidades envolvendo poder, status ou ganhos econômicos. ${ }^{4}$ Destarte, parece difícil acreditar que a visão das Cortes consubstancie a vontade definitiva da comunidade política em que nos inserimos sobre cada controvérsia que chega às Cortes, por mais "iluminista" que ela pareça ser. ${ }^{5}$

A segunda questão que a ideia da supremacia judicial levanta é a questão do custo dos direitos: ao fim e ao cabo, todo direito pressupõe a aplicação de recursos públicos e algum tipo de ação estatal. (HOLMES; SUNSTEIN, 1999, p. 44). Considerando que os direitos constitucionalmente garantidos não existem apenas para ficar no papel, é preciso ter em mente que, ao mesmo tempo que todo direito requer o dispêndio de certos recursos, estes, mesmo em países de primeiro mundo, são finitos, o que implica, necessariamente, realizar escolhas sobre alocação de recursos. (HOLMES; SUNSTEIN, 1999, p. 94-95). É passível de críticas, nesse sentido, defender que as cortes tenham a competência para desenhar políticas públicas, sem uma aprovação orçamentária prévia pelas instituições democraticamente eleitas. E é notório que decisões das Cortes sobre políticas públicas são cada vez mais comuns, sem que essas

\footnotetext{
${ }^{4}$ Essa ideia é trazida à tona por John Rawls, ao procurer construer uma tese de liberalismo politico fundada na ideia de divergência sobre direitos entre cidadãos razoáveis. (RAWLS, 2005, p. 58 e 243-245).

${ }^{5}$ Nesse sentido é a tese clássica de Alexander Bickel sobre a dificuldade contramajoritária envolvendo o Poder Judiciário e o controle de constitucionalidade (BICKEL, 1986, p. 28).
} 
decisões possuam soluções óbvias. Os juízes constitucionais são instados a se pronunciar em casos nos quais eles mesmos estão em desacordo, ou em que as palavras da Constituição são vagas, gerais, ambíguas, restando alternativas abertas e dissensos sobre as consequências, probabilidades e questões de valor que ordenam as alternativas. (DAHL, 2009, p. 26-27). Justamente aí reside o argumento da ausência de comprometimento prévio sobre direitos que Waldron coloca com o intuito de expor o déficit democrático do poder de revisão judicial.

Assim, tem-se como problemática a construção da ideia de supremacia judicial em uma sociedade que busca se qualificar como democrática. Os argumentos substancialistas de Waldron são fortes, e há poucas razões para confiarmos no corpo de juízes togados mais do que nos legisladores diretamente eleitos pelo voto, razão pela qual não há como questionar que a função primária de formulação de políticas públicas deve residir nas mãos destes. Afinal, um dos pontos fundamentais da democracia é justamente o autogoverno, o direito de o povo definir autonomamente o seu destino. Para tanto, o Judiciário desponta como o poder menos representativo entre todos, e com a menor capacidade para compor estratégias de ação, dado que está atado ao discurso jurídico, ao menos em tese. (HABERMAS, 2012, p. 239).

\section{A SEPARAÇÃO DE PODERES DIALÓGICA}

\subsection{CRÍTICA DO MODELO PURO E LIBERAL DE SEPARAÇÃO DE PODERES}

Waldron (2006, p. 1395) não nega que, em alguns casos, é possível que a revisão judicial sirva para dar voz às minorias quando os canais de acesso à política estejam bloqueados para elas. Em resumo, a ideia por trás dessa afirmação é a de que mesmo o Poder Legislativo pode ter falhas de representatividade, ignorando certos temas de relevância social inquestionável. Com efeito, apenas uma ideia mecanicista ou divina de Constituição poderia justificar uma definição espontânea e definitiva de meios e fins estatais a serem perseguidos automaticamente. ${ }^{6}$ Independentemente disso, por questões práticas, as decisões estatais precisam ter uma pretensão de perpetuidade para que sejam comandos de fato. Isso permite que muitas decisões sub-ótimas sejam moralmente obrigatórias para garantir a continuidade do próprio sistema político. (KYRITSIS, 2020, p. 2). Entretanto, o conceito de separação de poderes foi constituído historicamente para proporcionar calculabilidade e controle de toda ação estatal, com o intuito eminentemente liberal-burguês de proteger o indivíduo em face de intervenções estatais. (cf. SCHMITT, 2008, p. 175). A ideia de separação pura dos poderes formulada por Montesquieu (2008, p. 168-169) era no sentido de que, caso o executor das leis

\footnotetext{
${ }^{6}$ Nesse sentido é a teoria da constituição de Rudolf Smend (1986), que adota um viés mais sociológico na sua construção do conceito de Constituição.
} 
aplicasse suas vontades gerais, e não a lei, se tornaria um déspota; por isso, ele havia de ser controlado pela lei. Dessa maneira, o poder de julgar foi definido como nulo. (MONTESQUIEU, 2008, p. 172). O intuito era estabelecer opressões mútuas entre os poderes, de modo que cada um deles se sentisse igualmente forte e intimidado ante o poder dos demais. (GARGARELLA, 2013, p. 14-15). Inclusive, é notável na obra Os Federalistas (HAMILTON, 1864, p. 106) a predominância de uma ideia pessimista sobre o ser humano, o qual seria inerentemente mais inclinado a oprimir os seus diferentes, do que a cooperar com eles em busca do bem comum. Por isso, o papel das Cortes Constitucionais, definido ao fim e ao cabo por Kelsen (2007), foi pautado muito mais por uma ideia de controle - ou opressão aos demais poderes, por meio de decisões declaratórias de inconstitucionalidade.

O aumento das exigências sobre o Poder Judiciário em questões de cunho político e o desenvolvimento de análises mais empíricas do comportamento judicial acabou por desacreditar o modelo legalista de aplicação do Direito pelas cortes. É preciso compreender o seu processo de tomada de decisão como também sujeito às vicissitudes da política, com as suas decisões sendo resultado não de mera interpretação de estatutos legais, mas da sua interação com os outros poderes. (RODRÍGUEZ-RAGA, 2011, p. 85). Os juízes constitucionais dificilmente tomam decisões sem levar em conta os seus efeitos na esfera democrática, buscando minimizar a possibilidade de que sejam superadas. (HIRSCHL, 2007, p. 47). Smend (1986, p. 75-76) também já criticava a noção tecnicista de aplicação do Direito por juízes, pois eles participam na construção da função integradora do Estado, ainda que de modo secundário. Após a ascensão do Estado Social, a separação pura de poderes se tornou indesejável, se é que algum dia foi atingida de fato. (VILE, 1998, p. 349). É notório que todos os juízes não só julgam, mas executam; que os governantes executam, mas também legislam por decretos; e que os legisladores legislam, mas também julgam os integrantes dos outros poderes. E não é demais cogitar que o core case (caso central) da tese de Waldron beire a utopia mesmo no ocidente. A consideração do modelo estratégico de comportamento judicial na análise da separação de poderes acaba por tornar defasado o debate sobre se juízes constitucionais podem ou não interpretar de modo "ativista" a Constituição, e redireciona o debate para o estudo de quais incentivos políticos garantem sua maior independência, o que tem sido explorado pela ciência política.

$\mathrm{Na}$ teoria constitucional, o enfoque deve se pautar na composição ideal dos poderes, o que não pode mais ser visto exclusivamente sob a noção de legalidade. O Poder Judiciário é, sob esse ponto de vista, apenas mais um poder um componente de um sistema de governo 
mais amplo, em que diversos poderes e atores políticos interagem constantemente, buscando atribuir a sua própria significação às mesmas questões, ainda que por meio de diferentes processos de tomada de decisão, linguagens e formas de representação. O ponto central, aí, passa a ser, de um ponto de vista externo, do observador, quem detém a legitimidade para decidir em um determinado momento sobre um determinado tema, e, do ponto de vista interno - isto é, da instituição que toma a decisão - qual a melhor estratégia para que essa decisão seja durável, eficaz e, mais do que isso, legítima.

\subsection{O DIÁLOGO INSTITUCIONAL COMO MODELO NORMATIVO DE} SEPARAÇÃO DE PODERES

A compreensão de que seria um dos papeis do Estado a busca pela justiça social, renovada a partir do fim do século XIX, elevou os objetivos constitucionais a um nível de exigência que requer muito mais coordenação dos governos do que no passado, o que impregnou a atuação dos controles democráticos e do Poder Judiciário. (VILE, 1998, p. 381382). No entanto, uma separação de poderes fundada na promoção do conflito entre os poderes não colabora para a resolução de problemas complexos envolvendo políticas públicas. (GARGARELLA, 2013, p. 14-15). Desse modo, um novo modelo capaz de equilibrar controle e coordenação entre os poderes deve ser encontrado. Vile (VILE, 1998, p. 380) expõe que a tendência de todo arranjo institucional é, afinal, se reformular com novas combinações dentro desse mecanismo de acordo com as necessidades que surgem. Nesse sentido, a separação de poderes seria fluida, e não estática.

As Cortes, por serem parte do processo de integração, podem elas mesmas também atuar de modo a reforçar a legitimidade do sistema como um todo ao interpretar e efetivar a Constituição. (KYRITSIS, 2016, p. 99). Em outras palavras, é a legitimidade política que define com quem deve residir a decisão, em último caso, a depender do momento e dos resultados das prévias decisões, e não a partir de credenciais prévias e estáticas. (MENDES, 2011, p. 204). Uma divisão de funções equilibrada e coordenada faz com que a cada instituição incumba monitorar umas às outras no cumprimento de seus respectivos papéis. (KYRITSIS, 2016, p. 99), o que perpassa a mera função de controle recíproco.

Tem se destacado como expressão disso o conceito de diálogo institucional, como alternativa à dicotomia entre a supremacia legislativa ou judicial. (ROACH, 2004, p. 55). Surgiu a partir da pesquisa jurisprudencial de Peter Hogg e Alisson Bushell sobre casos julgados pela Suprema Corte Canadense após a promulgação da Carta de Direitos de 1982. Os autores identificaram que, na sua grande maioria, a decisão deixava espaço para o que 
chamam de "sequelas legislativas", de modo que quase sempre havia margem para que os outros poderes apresentassem respostas às decisões da Corte, que deixavam de ser necessariamente a decisão final sobre os direitos controvertidos em juízo. (HOGG; BUSHELL, 1997, p. 96).

O diálogo entre Cortes e Legislaturas ocorreria sempre que uma decisão judicial pudesse ser revertida, modificada ou evitada por uma nova lei, a qual cumpriria o mesmo desiderato, ainda que respeitando - e dialogando com - os valores identificados pela Corte como defendidos pela Carta de Direitos. (HOGG; BUSHELL, 1997, p. 90). Dessa forma, a Corte teria a capacidade de introduzir tópicos na agenda legislativa, os quais podiam ter sido ignorados ou não debatidos o suficiente, e poderia relembrar os outros poderes do pacto constitucional realizado, influenciando o desenho da nova legislação, sem com isso impor como ela deveria ser feita. (HOGG; BUSHELL, 1997, p. 80). Isso configuraria o início de um debate público qualificado, com uma comunicação interinstitucional sobre como conciliar direitos individuais com os objetivos de políticas econômicas e sociais. (MENDES, 2011, p. 150). Veja-se que essa noção específica sobre a dinâmica da separação de poderes não impede que o Poder Legislativo venha a prevalecer, eventualmente. Mendes (2011, p. 169-170) desenvolve essa ideia ao firmar os conceitos de rodada procedimental e última palavra provisória, indicando que, muito embora os mecanismos constitucionais de resolução de conflitos tenham um ponto final, as decisões sobre direitos sempre constituem apenas o fim de uma rodada, a qual pode ser recomeçada por outro poder. Mantém-se, por uma escolha constituinte, o poder hierárquico do Judiciário de resolver os conflitos, ainda que com menor importância, aumentando-se, porém, o controle democrático das suas decisões. (VILE, 1998, p. 364-366).

A separação de poderes dialógica é incompatível com a supremacia judicial. Trata-se de uma afirmação duplamente analítica e normativa: não só é impossível conseguir refrear totalmente os processos sociais e políticos com uma sentença final num processo, como também é desejável para o avanço de uma sociedade que pretende possuir um autogoverno, no seu senso mais democrático, que a comunidade política possa seguir debatendo os acertos e erros das suas instituições representativas, do que não escapa o Poder Judiciário. ${ }^{7} \mathrm{E}$ as questões sobre direitos podem retornar ao Legislativo quando esse reiniciar a rodada

\footnotetext{
${ }^{7}$ A ideia geral é retirada da obra de Mendes (2011, p. 169). Ele cita o caso da liberação do aborto nos EUA, via decisão judicial da Suprema Corte, defendendo que o trânsito em julgado de um processo constitui o fim da questão controvertida apenas para o Judiciário: a comunidade política, entretanto, é capaz de seguir debatendo o mérito da questão por muito tempo, inclusive propondo novas alternativas e tomando novas decisões.
} 
procedimental, aprofundando os seus argumentos ou alterando-os para cumprir o objetivo social ou econômico pretendido de modo diferente. Daí, o tema retorna ao processo majoritário amplo e representativo para conferir igual peso à opinião de cada membro do Parlamento sobre o que significam, afinal, os direitos. Em outras palavras, a separação de poderes dialógica exige que os poderes eleitos pelo voto retenham a responsabilidade primária sobre a política econômica e social, possuindo a competência de superar de alguma forma a decisão da Corte, ao mesmo tempo que respeitando os valores contidos na Carta de Direitos. (HOGG; BUSHELL, 2007, p. 3). A ideia é que as decisões judiciais que derrubam leis do Parlamento feitas conforme o processo legislativo geram um foro de debate público entre todos os poderes afetados. (HOGG; BUSHELL, 2007, p. 9-10). Os poderes podem e devem desafiar-se com razões melhores que as anteriormente apresentadas, sendo que as decisões continuam obrigatórias, mesmo que delas discordemos. Ao fim e ao cabo, haveria algum estímulo de deliberação entre os poderes com vistas a uma solução produtiva. (MENDES, 2011, p. 195). Isso contribui para manter a integridade do esforço institucional conjunto de cumprir os objetivos constitucionais, o que exige mais ação estatal nos dias de hoje. Desse modo, o Poder Judiciário deve poder também mobilizar uma pauta inerte ignorada pelos demais poderes. Isso pode ter um efeito epistêmico produtivo, servindo como correção de uma inércia patológica, tornando uma pauta estabilizada em reprimida; a intervenção judicial seria o único meio de testar o status quo, de modo a descobrir se ele é fruto do consenso ou de uma omissão indiferente. (MENDES, 2011, p. 232). Embora não se possa definir nosso sistema de controle de constitucionalidade como fraco,${ }^{8}$ é possível referir exemplos de diálogo institucional no nosso país, com a reatividade entre instituições gerando o aquecimento de pautas até então inertes. ${ }^{9}$

Quanto aos critérios para verificar a ocorrência dessa flutuação de legitimidade, é possível aproveitar categorias que justifiquem maior urgência na decisão em determinados casos e que possuam um significado mais central para o sistema político como um todo. (cf.

\footnotetext{
${ }^{8}$ Não se ignora, aqui, que Hogg et al, em seus ensaios, consideram fraco o sistema de revisão judicial no modelo canadense, sobretudo pela existência de cláusulas específicas na Carta de Direitos de 1982 que facilitam o diálogo. Ver o capítulo Features of the Charter that facilitate dialogue (HOGG; BUSHELL, 1997, p. 83-92.). O exemplo mais famoso é a Seção 33 - a cláusula de notwithstanding -, a qual permite que a legislatura mantenha, em alguns casos, um estatuto declarado inconstitucional pela Corte válido por 05 (cinco) anos, com possibilidade de renovação por igual período. O capítulo 4 busca apresentar alguns argumentos analíticos para demonstrar incentivos ao diálogo institucional, mas eles são internos ao próprio Poder Judiciário, o que pode ser uma limitação.

${ }^{9}$ Mendes (2011, p. 224-225) cita episódios de diálogo interinstitucional na nossa realidade brasileira, como no caso da Cláusula de Barreira, em que o Congresso erigiu a Emenda Constitucional n. 97/2017 em resposta à decisão do STF nas ADI's n. 1.351 e 1.354, evitando com isso, seguir a interpretação do Supremo sobre a inconstitucionalidade de tal cláusula.
} 
KYRITSIS, 2020, p. 9). Uma possível hipótese seria destacar certos direitos definidores de pré-condições para a democracia em si como requisito para uma maior interferência judicial. ${ }^{10}$ Com efeito, temas para os quais o desenho do processo legislativo e eleitoral possui maior dificuldade de representar adequadamente podem despontar como um truísmo nesse caso. Minorias sub-representadas no jogo político possuem maior risco, naturalmente, de ver seus direitos constitucionalmente assegurados violados por fruto de interesses sectários. (SUNSTEIN, 2008, p. 38).

\section{POTENCIAL DE APLICAÇÃO DO ECI DENTRO DA LÓGICA DIALÓGICA DE SEPARAÇÃO DE PODERES}

O Estado de Coisas Inconstitucional (ECI) é uma técnica de tutela de direitos construída pela jurisprudência da Corte Constitucional Colombiana (CCC) como resposta a violações sistemáticas de direitos fundamentais, tendo tido sua primeira aplicação em 1997. (COLÔMBIA, 1997). Foi aplicado em diversas oportunidades pela CCC, com variações em sua conformação (v. RODRÍGUEZ-GARAVITO, 2011; ARIZA, 2013)' mas pode se dizer que o seu núcleo conceitual envolve os seguintes elementos: deve haver um amplo número de pessoas alegando violações de direitos fundamentais; mais de um órgão deve ser tido como responsável pelas violações; e, por isso mesmo, a solução para o problema envolve a adoção de medidas estruturais, pois ações coordenadas de mais de um órgão são necessárias para a efetivação dos direitos. (RODRÍGUEZ-GARAVITO, 2011, p. 1671).

Já há críticas, não só sobre o caráter excessivamente ativista do ECI (STRECK; LIMA, 2017), mas, também, do ponto de vista pragmático, de que de que tal técnica decisória não seria capaz de alterar a realidade social como se propõe. (MAGALHÃES, 2019a). A primeira perspectiva preocupa-se com a discricionariedade judicial para a declaração do ECI, sobretudo, tendo em vista o grau de vagueza dos requisitos definidos para a sua aplicação. (MAGALHÃES, 2019, p. 16). Entende-se que essa é uma questão que foge da dogmática legal: Constituições como a brasileira e a colombiana acabam por apresentar textos extensos e, por vezes, até contraditórios no caráter dos direitos reconhecidos, de modo que é inevitável que qualquer questão constitucional permita leituras opostas por parte dos intérpretes. (GARGARELLA, 2018, p. 21-23). O diálogo institucional, ao conceber que os poderes podem responder com novas razões a decisões de outros poderes, até acomodar a questão política com uma decisão definitiva, procura justamente responder a essa preocupação com

${ }^{10}$ É o que propõe Cass Sunstein (2008, p. 32) como parâmetro para a adoção de uma postura "maximalista" ou "ativista" pelas cortes. 
uma perspectiva analítica de como a relação entre os poderes se dá, a despeito do que o modelo clássico de separação de poderes preconiza. A questão dos efeitos das decisões em ECI's, de outro lado, é o que se pretende analisar neste capítulo.

Fica evidente, a partir da linha de pensamento apresentada no tópico anterior, que a tomada de decisões e a sua implementação pelos poderes é um ponto central no diálogo institucional, pois o que se quer é aumentar as chances de que o arranjo institucional produza alterações no mundo dos fatos. Afinal, a ideia é descongelar pautas esquecidas pelo debate público. Portanto, a análise das decisões do Judiciário, quando este inicia uma rodada institucional, deve ser ampliada para abarcar outros efeitos que não apenas aqueles produzidos diretamente por sentença. (RODRÍGUEZ-GARAVITO, 2011, p. 1675-1676). Para Rodríguez-Garavito (2011, p. 1679-1681), além dos efeitos diretos, que se dão por ordem da Corte direcionada explicitamente a algum indivíduo, agente ou grupo, e materiais, que são tangíveis e notados a partir dessas ordens, seria importante verificar a produção de efeitos indiretos - consequências fáticas não estipuladas pela Corte, mas que derivam de uma decisão sua - e simbólicos - mudanças na percepção social sobre determinado tema sujeito à litigância. Uma decisão judicial que pudesse, desse modo, gerar uma ação institucional por parte de outros agentes políticos, sobre um tema que até então estava inerte, seria bem sucedida em termos de diálogo institucional.

Mas qual seria, então, o tipo de decisão judicial que melhor efetiva e conjuga todos esses efeitos? Para Rodríguez-Garavito (2011, p. 1691), é preciso que a Corte interrelacione adequadamente três fatores: conteúdo substancial da decisão sobre direitos, remédios judiciais aplicáveis para a sua efetivação e mecanismos de monitoramento. Interessante notar que, quanto ao primeiro aspecto, este costuma ser o único que recebe atenção na dogmática constitucional, acostumada com o caráter declaratório das decisões das cortes constitucionais. Não deixa, também, de ser ele um foco de uma retórica mais acentuada por parte dos juízes, que muito podem dizer, mas pouco efetivar, se a decisão não desenvolver os outros pontos. São estes que dizem respeito à efetivação dos direitos, residindo neles a controvérsia sobre como conciliar uma técnica decisória estrutural como o ECI com os paradigmas da democracia e da separação de poderes. Sob a perspectiva dialógica, a aplicação ideal do ECI se daria sob a seguinte conjugação dos três fatores citados:

This threefold characterization allows for an assessment of the monologic or dialogic character of a given ruling or court. The most dialogic decisions in structural cases involve a clear affirmation of the justiciability of the right in question (strong rights); leave policy decisions to the elected branches of power while laying out a clear roadmap for measuring progress (moderate remedies); and 
actively monitor the implementation of the court's orders through participatory mechanisms like public hearings, progress reports, and follow-up decisions (strong monitoring). (RODRÍGUEZ-GARAVITO, 2011, p. 1692).

Por um lado, a escolha pela Corte de aplicar remédios judiciais dialógicos seria conveniente pela compreensão de que a responsabilidade política primária sobre o desenho, a alocação de recursos, entre outros fatores atinentes à construção de políticas públicas, deve permanecer com as agencias governamentais, cujos representantes foram eleitos para esses fins. (RODRÍGUEZ-GARAVITO, 2011, p. 1691). De outra banda, um mecanismo de monitoramento dialógico permitiria a participação popular na construção das decisões pelos órgãos responsáveis, bem como garantiria um controle democrático, e não apenas judicial. (RODRÍGUEZ-GARAVITO, 2011, p. 1691). Trata-se de medida que legitima o ECI como instrumento mais democrático de intervenção judicial. (cf. GARGARELLA, 2013, p. 3).

Rodríguez-Garavito, em dois trabalhos, o primeiro sozinho (2011) e o segundo em conjunto com Rodríguez-Franco (2015), foi capaz de apresentar alguns elementos analíticos a favor dessa posição. Duas decisões podem ilustrar bem a sua tese: a Sentencia T-153, de 1998, que versou sobre o problema da superlotação carcerária (COLÔMBIA, 1998), e a Sentencia T-025, de 2004, na qual se enfrentou o tema do deslocamento forçado de famílias por conta de conflitos entre grupos paramilitares e as FARC (Forças Armadas Revolucionárias da Colômbia) no país. (COLÔMBIA, 2004). O motivo é o de que a Sentencia T-025/04 se sobressaiu quanto às demais decisões que declararam o ECI naquele país, em termos de efetivação de direitos (RODRÍGUEZ-GARAVITO; RODRÍGUEZFRANCO, 2015, p. 66-67). Por outro lado, a Sentencia T-153/98 constituiria um exemplo negativo por ter privilegiado uma combinação monológica de direitos e ordens fortes, renunciando a Corte ao rastreamento da decisão. (RODRÍGUEZ-GARAVITO; RODRÍGUEZ-FRANCO, 2015, p. 214).

No que toca à argumentação da Corte sobre sua competência para intervir em uma política pública, na T-153/98, a CCC afirmou que a inércia das autoridades vinha gerando a violação sistemática dos direitos dos presos, sem que, com isso, se notasse qualquer projeto político oficial para modificar tal situação. (COLÔMBIA, 1998). Para tanto, foram apresentadas muitas provas sobre a situação degradante das penitenciárias de todo o país. De outro lado, a CCC chamou a atenção para a ineficácia dos meios jurídicos e administrativos para conter o problema, indicando que o ponto chave era a ausência de representação política dos presos enquanto minorias, e que o problema não se resolveria com uma simples declaração de inconstitucionalidade. (COLÔMBIA, 1998). 
Na T-025/04, a CCC reconheceu que a situação precária dos deslocados se deu por conta de uma prolongada omissão das instituições colombianas, de modo análogo ao que ocorreu na T-153/98. (RODRÍGUEZ-GARAVITO; RODRÍGUEZ-FRANCO, 2015, p. 66). Havia um verdadeiro bloqueio institucional que impedia a solução do problema do deslocamento forçado das famílias pelo país afora, por conta da conjugação de elementos de passividade e descoordenação estatal, o que tornava as leis sobre o assunto inefetivas. Outro fator importante era o de que desde 2000 a CCC já julgava questões relativas ao fenômeno do desplazamiento forzado, como no caso da Sentencia SU-1150/2000. (COLÔMBIA, 2000).

Em ambas as decisões, foram definidos direitos fortes em prol dos grupos representados. A CCC, na T-153/98 fez importantes considerações sobre a violação dos direitos dos presos, postos em situações desumanas, que beiravam a tortura. (ARIZA, 2013, p. 132). E reconheceu, ao longo do cumprimento da T-025/04, que a inércia estatal prejudicava ainda mais certos grupos vulneráveis, vindo a declarar uma proibição de discriminação com minorias sociais e adversários políticos, e que os recursos escassos deveriam ser aplicados em escala de prioridade e de modo a garantir uma proteção mínima de seus direitos. (COLÔMBIA, 2004). Com isso, tem-se que, tanto na T-198/98 quanto na T-025/04, a CCC se baseou numa ideia de legitimidade política para avaliar se poderia interferir na questão. Ao final, sua análise pendeu para a judicialização do caso, porquanto os poderes eleitos claramente vinham lidando de maneira apática e desconsiderada com esses temas tão sensíveis. E, para conferir credibilidade à tese, foram apresentados argumentos sociológicos, históricos e empíricos que indicavam a omissão dos poderes públicos em lidarem com as questões postas em juízo, afetas a minorias sistematicamente ignoradas pelos poderes públicos. Trata-se de um ônus argumentativo fundamental para conferir legitimidade à interferência da Corte, não somente junto à sociedade civil, mas também em face dos demais poderes que sofrerão sua intervenção.

A situação muda quando se passa à análise dos remédios judiciais e da forma de monitoramento das decisões que a CCC optou em cada caso. A T-153/98 pecou por emitir ordens rígidas e inflexíveis demais, com prazos pré-estabelecidos por ela mesma, surrupiando a possibilidade de qualquer diálogo institucional. (RODRÍGUEZ-GARAVITO; RODRÍGUEZ-FRANCO, 2015, p. 217). Logo nos autos do acórdão já constou a emissão de ordens ao Ministerio de Justicia y del Derecho e demais órgãos competentes para o desenho de um plano total de reconstrução do sistema carcerário, "tendente a garantizar a los reclusos condiciones de vida dignas en los penales", no mísero prazo de 03 (três) meses. (COLÔMBIA, 1998). Os custos de tais medidas foram definidos como sendo de 
responsabilidade imediata do Governo Central, que deveria "realizar de inmediato las diligencias necesarias para que en el presupuesto de la actual vigencia fiscal y de las sucesivas se incluyan las partidas requeridas." (COLÔMBIA, 1998). Com isso, não houve o chamamento de órgãos representativos ao debate, sufocando qualquer possibilidade de diálogo e de desenho coordenado de políticas públicas.

A T-153/98 também não contou com nenhuma forma de monitoramento judicial dos impactos da decisão. No próprio acórdão, a CCC indica que o processo de fiscalização do cumprimento da decisão ficaria nas mãos da Defensoría del Pueblo e da Procuraduría General de Nación, para exercer "supervigilancia”" sobre o cumprimento das ordens emitidas. (COLÔMBIA, 1998). Com isso, a CCC se absteve de participar do rastreamento da decisão, o que também retirou o caráter normativo das ordens emitidas no processo de rastreamento aos poderes públicos responsáveis, flexibilizando o seu cumprimento. A Corte atuou muito mais no sentido clássico, exercendo uma função declaratória de inconstitucionalidade, eximindo-se, no entanto, de qualquer papel institucional na concretização das políticas públicas que não seja um novo controle repressivo no futuro, mediante nova ação judicial declaratória. Para ARIZA (2013, p. 134), a Corte até piorou a situação, pois aplicou uma visão "conservadora" sobre o sistema penitenciário, no sentido de incentivar a expansão das vagas em presídios como solução para o problema. Portanto, a adoção de uma postura monológica, em caso de declaração e ECI, além de impedir que posições alternativas influenciassem o debate sobre o tema, permitiu que o ECI servisse de instrumento para a erosão de direitos constitucionalmente garantidos por conta de uma visão unilateral da Corte.

De modo oposto, na T-025/04, a CCC não se limitou a declarar a violação massiva de direitos, mas arrogou para si a jurisdição para levar adiante um processo de rastreamento detalhado do desempenho do Estado após a sentença. (RODRÍGUEZ-GARAVITO; RODRÍGUEZ-FRANCO, 2015, p. 66). A Corte deixou claro na sentença inicial que o fato de não deter a competência primária para dar cabo de políticas públicas não a impediria de suscitar a questão, em clara sinalização de que um tópico acerca de direitos poderia ser introduzido pela Corte na agenda legislativa. (COLÔMBIA, 2004). Essencialmente, foram quatro as principais medidas tomadas para a efetivação da decisão, (RODRÍGUEZGARAVITO; RODRÍGUEZ-FRANCO, 2015, p. 67-68): (i) a realização de audiências públicas com Ministérios, órgãos públicos e associações, a partir de informações a eles requeridas; (ii) a realização de sessões técnicas e públicas, em locais fora da capital Bogotá, com os funcionários e grupos interessados convocados pela CCC para debater um assunto 
específico; (iii) a criação da Sala Especial de Seguimiento, órgão responsável por avaliar o progresso, o atraso e os inconvenientes envolvendo a superação do ECI, sendo composto por três magistrados, um magistrado auxiliar e cinco assistentes; e (iv) a expedição dos autos de seguimiento, decisões judiciais para “monitorear la implementacións de las órdendes impartidas en la T-025, solicitar informes y acciones concretas de actores específicos [...]." A T-025/04 constituiu, nesse sentido, importante exemplo de diálogo institucional, porquanto permitiu a coordenação de diversos atores sociais e instituições, conciliando o controle democrático com a capacidade de coordenação dos poderes públicos. Dezenas de audiências públicas e sessões técnicas foram realizadas para prestações de contas e debates públicos sobre os resultados obtidos. (RODRÍGUEZ-GARAVITO; RODRÍGUEZ-FRANCO, 2015, p. 145-146). A responsabilidade pela criação das políticas públicas ficou claramente sob os poderes democráticos (RODRÍGUEZ-GARAVITO, 2011, p. 1693).

Os efeitos da T-025/04 também são mais impactantes, indo bem além daquilo que as decisões judiciais da CCC diretamente produziram. (RODRÍGUEZ-GARAVITO, 2011, p. 1687-1688). A T-025/04 foi capaz de gerar respostas diretas dos demais Poderes representativos ao longo da sua execução. Com efeito, após a sentença, foram aprovadas as Leis n. 975 de 2005 (COLÔMBIA, 2005) e n. 1448 de 2011 (COLÔMBIA, 2011), as quais decorreram da influência da Corte sob os demais poderes. (DÍAZ, 2017, p. 41). A primeira, aprovada pouco tempo depois da T-025/04, tornou crime o ato do desplazamiento forzado, enquanto que a segunda buscou garantir um marco de justiça de transição para os deslocados. (COLÔMBIA, 2005). Disso decorreram também outras atitudes significativas do Governo no enfrentamento do problema, as quais hoje são administradas por ramos do Poder Executivo, como a Unidad para la atención y Reparación Integral a las Victimas ${ }^{11}$, criada pela Ley n. $1448 / 2011$.

Importantes efeitos indiretos também foram produzidos, como o surgimento de coalizões espontâneas entre diversos segmentos da sociedade civil que, no início, se deu pela força coatora da Corte. (RODRÍGUEZ-GARAVITO; RODRÍGUEZ-FRANCO, 2015, p. 153). Além disso, a Corte emitiu 289 autos de seguimiento para monitorar os efeitos da decisão nos 10 (dez) anos seguintes à sentença, a fim de requerer informações de sujeitos específicos, estabelecer audiências, analisar descumprimentos e avaliar a realização dos

\footnotetext{
${ }^{11}$ Conforme página inicial, "La Unidad para la Atención y Reparación Integral a las Víctimas es una institución creada en enero de 2012, a partir de la Ley 1448, de Víctimas y Restitución de Tierras, por la cual se dictan medidas de atención, asistencia y reparación integral a las víctimas del conflicto armado interno." Disponível em: https://www.unidadvictimas.gov.co/es/la-unidad/resena-de-la-unidad/126 , acesso em 27/01/2020, às 20h19min.
} 
direitos dos afetados pela decisão. (RODRÍGUEZ-GARAVITO; RODRÍGUEZ-FRANCO, 2015, p. 144). Isso aumentou a publicidade e a transparência do processo e do problema do desplazamento, que era até então ignorado, além de uma participação popular efetiva na construção das políticas. Cumpre referir também o efeito indireto da T-025/04 de recolocar os termos do debate, no sentido de que a CCC pôde deslocar o eixo da análise do problema, que antes era visto como "efeito colateral de um conflito armado", para uma questão de direitos humanos. (RODRÍGUEZ-GARAVITO, 2011, p. 1687).

As possíveis críticas à atuação da Corte se resumem à atuação mais ativista da Corte no que diz respeito aos grupos vulneráveis, emitindo ordens mais específicas. Nada obstante, Rodríguez-Garavito e Rodríguez-Franco (2015, p. 118) deixam claro que a CCC já havia requerido, de forma geral, ações do Governo quanto a esses grupos, o que não foi feito. Portanto, mesmo dentro do processo de rastreamento da decisão, a Corte manteve a ideia de legitimidade política como sendo o norte para verificar a qual ramo do Poder Público caberia a decisão sobre cada tema, havendo momentos em que arrogou para si o poder de requerer o desenho das políticas públicas que julgou necessárias, ainda que agindo preferencialmente de modo deferente aos demais poderes. Isso vai na linha da noção de que a legitimação dos poderes flutua conforme a atuação de cada um deles, e não conforme credenciais préestabelecidas.

\section{A ADPF 347/DF: MEDIDA CAUTELAR INSUFICIENTE, PAUTA} CONGELADA POR OMISSÃO DO SUPREMO

A ADPF 347/DF (BRASIL, 2015) foi proposta pelo Partido Socialismo e Liberdade (PSOL), possuindo diversos pedidos em sede liminar e de mérito. Mesmo em caráter liminar, a petição pedia a adoção de medidas estruturais pelo Supremo, como o reconhecimento de que os juízes da execução penal possam abater tempo de pena em casos de cumprimento de pena excessivamente severo em função das condições das penitenciárias (alínea “f”), a realização de mutirões carcerários para revisão de execuções penais pelo Conselho Nacional de Justiça CNJ (alínea “g”), entre outras. No mérito, a ação contém, além do pedido de declaração do ECI (alínea "a" da petição inicial, no mérito), os pedidos de determinação ao Governo Federal para que encaminhe ao STF, de 3 em 3 (três em três) meses, um plano nacional de superação do quadro inconstitucional num prazo de 3 (três) anos (alínea "a"), que o plano preveja os recursos necessários para a sua efetivação (alínea "d"), e que cumpra ao STF homologar (alínea “i”) e monitorar a implementação (alínea “j”) dos planos. (BRASIL, 2015). 
Pode-se dizer que a decisão tomada pelo Supremo em sede de Medida Cautelar (MC) teve uma recepção mista. Houve quem chamasse-a de "uma grande decepção" (GLEZER; MACHADO, 2015), mas também há trabalhos elogiando a postura do tribunal em tentar resolver problemas sociais latentes. (MARIANO; FURTADO; MAIA, p. 199-200). Na prática, contudo, tem-se que a decisão não pode ser considerada como declaratória de um ECI. Isso porque as medidas deferidas pelo Supremo não possuíram qualquer caráter estrutural. Nada obstante, é preciso ter em mente que o mérito da questão ainda pende de julgamento, o que torna relevante se realizar uma análise dos possíveis méritos da decisão liminar, bem como buscar averiguar a legitimidade da aplicação do ECI pelo Supremo.

Um aspecto louvável da decisão (BRASIL, 2015) foi o esforço argumentativo dos Ministros em justificar o grau de defesa dos direitos sociais dos presos, ao fundamentar a legitimidade do STF para julgar o caso. O Min. Marco Aurélio, relator da ação, iniciou seu voto afirmando que o STF teria essa missão de defender minorias. E, para comprovar que isso de fato era exigido no caso enfrentado, conferiu atenção especial ao contexto social e histórico da situação nas penitenciárias, a fim de embasar a tese de que existe uma violação massiva de direitos humanos. Foram citados estudos estatísticos de diversas instituições indicando o déficit gigantesco de vagas no sistema presidiário, com uma população carcerária dentre as maiores do mundo e sofrendo em eterna degradação nas instalações inadequadas. Haveria, ainda, falta de agentes penitenciários, baixa remuneração aos já contratados, constantes massacres e rebeliões, num quadro que se generalizou por toda a Federação.

O bloqueio institucional e a sub-representação eleitoral da população carcerária também foram destacados em diversos votos como fator central para legitimar uma intervenção estrutural pela Corte. O Ministro Marco Aurélio citou a "falta de coordenação institucional" e a "sistemática inércia e incapacidade das autoridades públicas em superálo." Por fim, concluiu que apenas o Supremo seria capaz de superar os bloqueios políticos e institucionais, cabendo a ele, nesse caso, "o papel de retirar os demais Poderes da inércia, catalisar os debates e novas políticas públicas, coordenar as ações e monitorar os resultados." Acompanhando o seu voto, o Min. Edson Fachin falou em uma falta de cumprimento de promessas legislativas pelo Congresso Nacional. Além de também citar dados estatísticos indicando a situação dramática dos presídios, aprovou o uso da ADPF como instrumento de defesa de direitos humanos pelos partidos minoritários do Congresso, como verdadeira ultima ratio. Para o Min. Luís Roberto Barroso, a essência da legitimação do STF para declarar o ECI residiria no fato de que os presos constituem uma minoria popular sem 
voz, tendo seus direitos mais elementares vulnerados. Os Ministros Luiz Fux, Teori Zavascki e Gilmar Mendes também desprenderam argumentos análogos. (BRASIL, 2015).

É importante referir que a questão das violações de direitos em presídios já vinha chegando à alçada do Supremo em diversas ações, tais como os Recursos Extraordinários n. 580.252/MS e n. 641.320/RS (cf. HABER, 2016), o que foi lembrado pelo Min. Marco Aurélio. (BRASIL, 2015). Nesse aspecto, a decisão do Supremo em declarar um ECI estaria de acordo com um requisito comumente citado pela $\mathrm{CCC}$, que seria a necessidade de a Corte tomar uma medida estrutural para evitar o congestionamento da Justiça com novas demandas processuais. Pode-se dizer, diante disso, que a decisão cumpriu importante papel na declaração do grau de proteção a ser concedido aos direitos dos presos enquanto minoria política. Foi destacada a dificuldade do grupo representado de acessar os canais ordinários da política do dia a dia, bem como a constante procura do Poder Judiciário para a proteção dos seus direitos sistematicamente violados. Entretanto, a decisão não passou disso, sendo praticamente omissa - ou fraca, na classificação de Rodríguez-Garavito (2011) - no que toca aos remédios judiciais e ao mecanismo de monitoramento da decisão pelo Plenário.

Tabela 1 - Avaliação da decisão do STF na ADPF 347 MC

\begin{tabular}{|l|l|l|l|l|}
\hline Decisão & $\begin{array}{l}\text { Visão sobre } \\
\text { direitos }\end{array}$ & Remédios judiciais & Monitoramento & Impacto \\
\hline T-025/04 & Forte & Moderados & Forte & Alto \\
\hline T-153/98 & Forte & Fortes & Fraco & Baixo \\
\hline ADPF 347 MC & Forte & Fracos & Fraco & Baixo \\
\hline
\end{tabular}

Fonte: inspirada na tipologia formulada por Rodríguez-Garavito (2011) e na classificação que o autor realizou de decisões análogas tomadas pela CCC (2011, p. 1695).

Quanto aos remédios judiciais definidos pelo Supremo, o Min. Marco Aurélio foi o que aderiu às medidas estruturais mais radicais propostas pelo partido político requerente. Considerou adequados os diversos pedidos atinentes ao controle da qualidade das decisões judiciais que contribuem para o encarceramento em massa, como reconhecido pelo próprio Supremo como problema central na questão prisional (GLEZER; MACHADO, 2015), tais como a determinação de que toda decisão que prive liberdade de modo cautelar justifique expressamente o porquê de não se adotar medidas alternativas, ou então que se observe a declaração do ECI a cada medida cautelar adotada, sempre se levando em conta medidas alternativas à prisão. (BRASIL, 2015). O Ministro Roberto Barroso, de outro lado, embora 
tenha afirmado que "[e]xiste um conjunto de ações e omissões notórias que fazem com que se tenha esse estado de generalizada inconstitucionalidade por falha estrutural do sistema", indeferiu tais pedidos por entender que eles já decorreriam da lei penal brasileira. (BRASIL, 2015). Tal posição acabou prevalecendo, pois apenas dois pedidos foram acolhidos: alínea "b" - que se reconheça a aplicabilidade imediata dos arts. 9.3 do Pacto dos Direitos Civis e Políticos e 7.5 da Convenção Interamericana de Direitos Humanos, determinando a todos os juízes e tribunais que passem a realizar audiências de custódia, no prazo máximo de 90 dias, de modo a viabilizar o comparecimento do preso perante a autoridade judiciária em até 24 horas contadas do momento da prisão - e alínea "h" -que se imponha o imediato descontingenciamento das verbas existentes no Fundo Penitenciário Nacional - FUNPEN, e vede à União Federal a realização de novos contingenciamentos, até que se reconheça a superação do estado de coisas inconstitucional do sistema prisional brasileiro. (BRASIL, 2015). O STF também não tomou nenhuma medida no sentido de manter a competência para monitorar a implementação do que decidiu. Logo, fica demonstrado que, a despeito da forte retórica proferida pelos Ministros, os remédios judiciais adotados foram praticamente nulos, assim como inexistiu a adoção de qualquer mecanismo de monitoramento judicial sobre aqueles pedidos deferidos na MC.

Além disso, imperioso compreender quais efeitos externos à decisão judicial a MC deferida parcialmente na ADPF 347 produziu. ${ }^{12}$ Um rápido retrospecto sobre a produção legislativa dos últimos anos, após a decisão ser proferida, é capaz de demonstrar que o STF não foi capaz de produzir quaisquer efeitos materiais ou simbólicos, sejam diretos ou indiretos, de modo significativo. Houve algumas leis no período com teor ambíguo, como as Leis n. 13.257/16 (BRASIL, 2016) e 13.769/18 (BRASIL, 2018), que garantiram direitos a gestantes encarceradas, tendo por base conferir maior proteção à primeira infância, principalmente, e a Lei n. 13.964/19 (BRASIL, 2019a), que, embora tenha sido popularmente chamada de "lei anticrime", instituiu importantes mudanças no processo penal brasileiro, como a necessidade de fundamentação expressa de quaisquer decisões judiciais, alguns requisitos limitadores da prisão em flagrante e preventiva, e o controverso instituto do juiz de garantias. No entanto, a lei traz elementos de continuidade do cenário de política de encarceramento em massa, pois promoeu, por exemplo, o aumento do limite máximo de penas para 40 (quarenta) anos. ${ }^{13}$ (BRASIL, 2019). A Lei n. 13.869/19 (BRASIL, 2019) também

\footnotetext{
${ }^{12}$ Agradeço às sugestões de parecerista anônimo sobre a importância desse ponto.

${ }^{13}$ Art. $2^{\circ}$ O Decreto-Lei $n^{\circ} 2.848$, de 7 de dezembro de 1940 (Código Penal), passa a vigorar com as seguintes alterações:
} 
exprime isso, pois diversos dispositivos que pretendiam coibir abusos na realização de prisões tidas por ilegais foram vetados sob justificativa de que dificultariam tais prisões. (BRASIL, 2019).

Mesmo o STF fez a sua parte em reforçar o caráter punitivista e hipertrofiado do sistema penitenciário nacional, embora nem sempre de modo unívoco. A começar pelo julgamento da constitucionalidade da prisão em segunda instância. Em fevereiro de 2016, já após a ADPF 347 MC ter sido julgada, o STF reverteu sua jurisprudência sobre o tema, consolidada em 2009 (MIGALHAS, 2019), e definiu a sua possibilidade. Ainda em 2016, o posicionamento foi mantido no julgamento de liminares nas ADC's 43, 44 e 54, só sendo desfeito no julgamento de mérito de 2019 (BRASIL, 2019b). Pode ser citada também a decisão de suspensão do instituto do juiz de garantias na ADI 6299 MC (BRASIL, 2020), em decisão monocrática que vigora ainda hoje. É possível criticar, ademais, que o STF tenha deferido na ADPF $347 \mathrm{MC}$ apenas decisões que deixem o encargo das violações dos direitos dos presos sobre eles mesmos, visto que em nenhum momento a Corte deferiu quaisquer pedidos que facilitem sua soltura em função das condições dos presídios, reconhecidamente impróprias. Ademais, a principal estratégia adotada pela Corte - liberação de verbas do Fundo Penitenciário - indica sua compreensão de que o problema se resolverá com mais e melhores presídios. (cf. ARIZA, 2013, p. 134). Nada obstante, o Supremo tem afirmado, mesmo durante a pandemia do COVID-19, a imprescindibilidade da realização das audiências de custódia, nos termos da MC (BRASIL, 2020). É possível citar, ainda o HC 143.641, de 2018 (BRASIL, 2018a), paradigmático por ter sido concedido de modo coletivo a gestantes ou mães de crianças de até 12 anos ou de pessoas com deficiência, entendimento que foi repetido, por exemplo, no HC 188.820 (BRASIL, 2021), permitindo a conversão de prisões cautelares em prisão domiciliar ou em liberdade provisória para presos de grupos de risco durante a pandemia. Em ambos os HC's, a ADPF $347 \mathrm{MC}$ foi citada como precedente da Corte apto a embasar a posição tomada.

O caráter ambíguo das decisões do STF deixa em aberto a questão sobre se o ECI, na extensão em que declarado, produziu algum efeito simbólico apto a refletir em como o Judiciário, a começar pelo próprio STF, entende o problema das penitenciárias brasileiras e do encarceramento em massa. Sobretudo o fato de o julgamento de mérito da ADPF aguardar ainda hoje por ser colocado em pauta pode indicar uma postura omissa por parte do Supremo (cf. MENDES, 2020) ou, no mínimo, de contentamento com os resultados da MC. Dois 
outros efeitos são importantes para notar alguma repercussão da decisão do Supremo, indo para além do âmbito judicial: o efeito sobre as políticas públicas e o efeito do enfoque dado ao problema, este último de caráter mais simbólico, conforme Rodríguez-Garavito (2011, p. 1684-1687).

A questão do debate sobre o tema na imprensa continua sob o mesmo enfoque. Em 2020, anos depois da ADPF 347 MC ser proferida e já debaixo da sombra da pandemia mundial do Coronavírus, a tônica das ações públicas sobre o problema das prisões no Brasil segue sendo o de expandir o sistema carcerário, sem atentar para medidas de assistência aos presos. (RIBEIRO, 2020). A Cruz Vermelha, entidade internacional, publicou o seu Balanço Humanitário do ano de 2020 destacando a vulnerabilidades dos presos diante da COVID-19. (METRÓPOLES, 2021). Já em 2021, há dados de que o número de óbitos por COVID-19 nas penitenciárias aumentou em 190\% em relação a 2020, conforme levantamento do Conselho Nacional de Justiça. (BRASIL DE FATO, 2021).

Isso pode ser um reflexo de que a decisão do Supremo tampouco produziu efeitos sobre como as políticas públicas envolvendo esse problema são tocadas no Brasil. Além dos dados trazidos por Djamila Ribeiro (2020), no sentido de que o foco segue sendo o mesmo aumentar vagas em estabelecimentos prisionais -, os dados acerca do investimento público desde a decisão do STF também confirmam o ponto.

Gráfico 1 - Investimento público no sistema prisional brasileiro em milhões de reais (20172020)

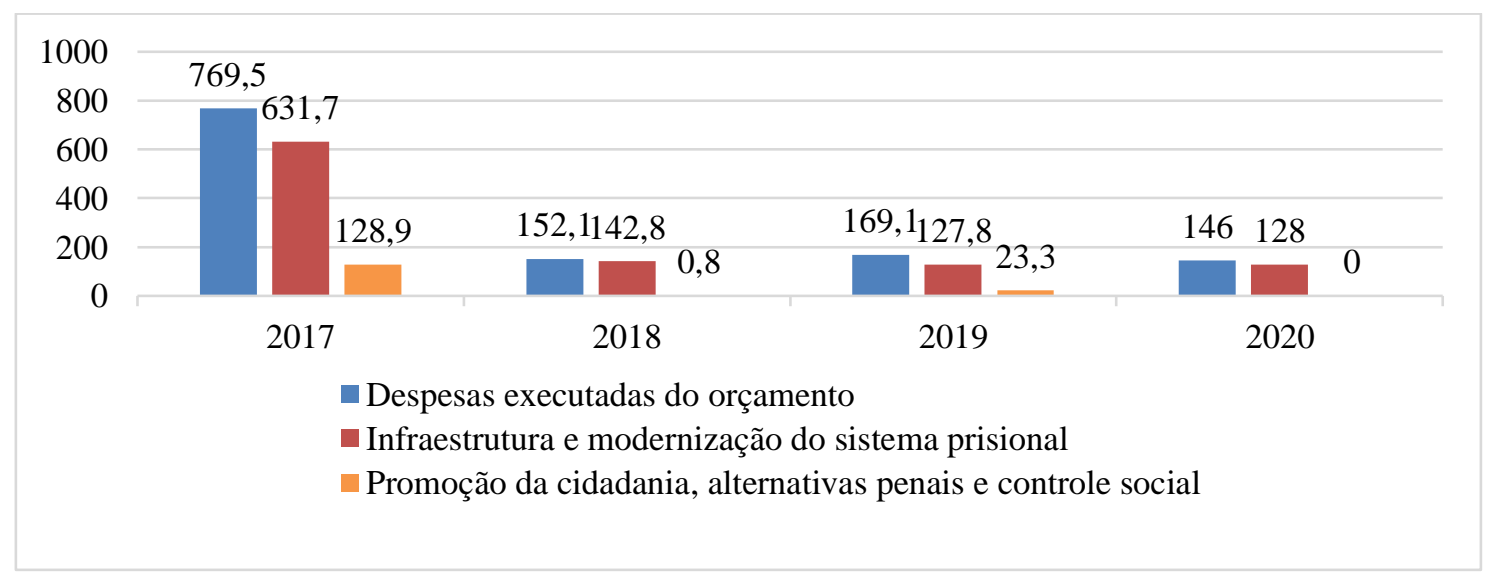

Fonte: Fundo Penitenciário Nacional - FUNPEN. (CONTROLADORIA-GERAL DA UNIÃO, 2021). 
Conforme demonstra o Gráfico 1, os investimentos em infraestrutura e modernização do sistema prisional prevalecem sempre sobre os investimentos em alternativas penais. ${ }^{14}$ (CONTROLADORIA-GERAL DA UNIÃO, 2021). Além disso, é curioso notar a disparidade dos investimentos realizados em 2017 com os demais anos: trata-se do ano em que se executou o orçamento aprovado no final de 2016, quando a ADPF 347 MC tinha sido proferida há pouco tempo. Foi justamente em 2017 que os investimentos no setor prisional foram os maiores. ${ }^{15}$ Foi também em 2017 que os investimentos em medidas alternativas à estruturação das penitenciárias em si ganharam maior espaço no orçamento federal, sendo reduzido a zero, praticamente, nos anos imediatamente posteriores. Nisso reside outro fator apto a indicar que a ausência de monitoramento judicial da ADPF 347 MC pelo Supremo contribuiu para tornar uma das poucas medidas deferidas na decisão praticamente inócuas. É preciso destacar que o número de presos não diminuiu em nenhum momento desde então: pelo contrário, só aumentou. Em 2016, a população prisional brasileira era de 722.120 presos (INFOPEN, dez./2016), com leve redução nos números no final de 2017 (INFOPEN, dez./2017), e aumento constante até alcançar a marca de 748.009 presos no fim de 2019, inclusive, com aumento de cerca de 40 mil presos em regime fechado em relação a 2018. (INFOPEN, dez./2019).

\section{CONCLUSÕES}

Passados mais de 30 (trinta) anos da promulgação da Constituição de 1988, a concretização de diversas das suas promessas segue em disputa nos foros públicos do país. Uma dessas searas é o Poder Judiciário, que tem o ápice da sua representação no Supremo Tribunal Federal. O Supremo tem desenvolvido uma jurisprudência de forte interferência na política nacional, o que tem gerado críticas e preocupações na literatura constitucionalista, que vê nessa postura mais ativa da Corte um problema para a separação de poderes e para a democracia. Neste trabalho, busquei diminuir, na medida do possível, a distância do controle

\footnotetext{
${ }^{14}$ Os indicadores são agrupados no Portal da Transparência (2021) sobre os seguintes títulos: (i) aprimoramento do sistema penitenciário nacional e incentivo ao desenvolvimento da inteligência penitenciária; (ii) racionalização e modernização do sistema penal; (iii) aprimoramento da infraestrutura e modernização do sistema penal; (iv) consolidação do sistema penitenciário federal; (v) promoção da cidadania, alternativas penais e controle social; (vi) capacitação e qualificação em serviços penais; (vi) construção e aprimoramento da penitenciária federal em Itaquitinga/PE; (vii) construção e aparelhamento da Quinta Penitenciária Federal; (viii) enfrentamento da emergência de saúde pública de importância internacional decorrente do Coronavírus. Considerou-se que todos os indicadores identificados, com exceção do indicador (v), dizem respeito a medidas de expansão do sistema penitenciário, no sentido criticado como sendo a política já adotada antes da ADPF 347 MC para enfrentamento da questão prisional. Por isso, todas os demais foram somados para constituir a coluna "Infraestrutura e modernização do sistema prisional."

${ }^{15}$ O Portal da Transparência registra os dados do orçamento do FUNPEN desde 2017.
} 
de constitucionalidade desses dois pilares do nosso Estado Democrático de Direito inaugurado pela Constituição de 1988.

Conforme sustentado na primeira parte do trabalho, a separação de poderes é, antes do que um modelo rígido e bem definido de competências, um arranjo institucional que varia conforme o tempo, inclusive, por ação dos seus próprios componentes. Desse modo, não teria sentido tomar partido entre a supremacia judicial ou a soberania parlamentar. Também se defendeu que, com a virada de paradigma do Estado Liberal para o Social, as questões constitucionais do nosso tempo demandam uma atuação conjunta dos poderes, sobretudo no caso de políticas públicas inexistentes e/ou ineficientes. Assim, adotando-se um conceito de separação de poderes fundado na ideia de legitimidade política, torna-se cabível a flutuação do poder de tomada de decisão entre os poderes de acordo com o contexto e a gravidade das violações de direitos constatadas. O diálogo institucional, nesse sentido, seria o modelo normativo de separação dos poderes, devendo-se refletir, a cada decisão tomada, se o poder que a tomou era o mais legitimado naquele determinado momento e contexto, o que pode justificar uma interferência por outro poder, mesmo se não for o responsável primário. $\mathrm{Na}$ tomada de decisões que demandam uma maior coordenação dos poderes, como é o caso de omissões inconstitucionais estruturais, o Poder Judiciário deve tomar uma postura mais dialógica, que permite, de modo estratégico, que a Corte tenha mais apoio e informação para efetivar suas decisões. Considera haver elementos empíricos aptos a indicar que essa estratégia é a que permite efeitos materiais e também simbólicos mais importantes.

No caso do Estado de Coisas Inconstitucional, propõe-se que as Cortes tenham de se desincumbir de um ônus argumentativo a respeito da sua legitimidade para julgar, haja vista a gravidade da interferência judicial nesse caso. Os casos concretos da Corte Constitucional Colombiana analisados apresentam como pressupostos a verificação de condições estruturais de sub-representação democrática e de descaso excessivo do poder público para com estas minorias. Trata-se de importante critério a ser empregado para conferir a possibilidade de controle externo pelos demais poderes, bem como parâmetro que confere credibilidade à interferência das Cortes, o que foi seguido pelo STF na decisão liminar proferida na ADPF n. 347/DF.

Buscou-se mostrar, ademais, que as decisões judiciais que visam à aplicação de medidas estruturais, como é o caso do ECI, devem se ater a três fatores que se relacionam para refletir no impacto da decisão: a visão sobre os direitos em jogo, os remédios judiciais aplicados e os mecanismos de monitoramento a ser definidos pela Corte. Estudos analíticos acabam demonstrando uma maior efetividade daquelas decisões da CCC em que os direitos são tidos 
de crucial importância, reconhecendo-se sua importância e a inadmissibilidade de sua violação. Esse foi o caso tanto da T-153/98, quando da T-025/04, as duas decisões analisadas. No entanto, os remédios judiciais a serem escolhidos são o ponto de maior controvérsia para as Cortes: a aplicação de ordens inflexíveis e rígidas diretamente a órgãos públicos apresenta não só um risco à democracia e à separação de poderes, como promove baixa colaboração dos demais poderes. A ausência de um monitoramento judicial tampouco contribui nesse sentido, pois, assim como o item anterior, bloqueia a participação popular na construção das políticas públicas, além de tornar a decisão pouco efetiva, esfriando o debate público. Assim, concluise que uma decisão judicial que opte por remédios judiciais moderados, com abertura para que os responsáveis moldem as políticas públicas, aliado a um forte acompanhamento pela Corte Constitucional no processo de efetivação e de construção das soluções, inclusive, com abertura para a participação popular nos debates, constitui a melhor estratégia sob o ponto de vista do diálogo institucional.

A partir desse quadro teórico, chega-se à conclusão de que o STF muito pouco fez com sua decisão na ADPF 347 MC. Embora tenham os Ministros adotado um discurso de forte proteção aos direitos dos presos enquanto minoria sub-representada, a Corte não tomou nenhuma medida de cunho estrutural, o que impede a caracterização da decisão como sendo declaratória de um ECI. As duas únicas medidas deferidas, em caráter liminar, constituem a aplicação de leis já postas, além de reforçar o cunho punitivista do sistema carcerário nacional, cujo reflexo é sentido no aumento do número de presos desde então em ritmo constante. Com isso, o STF gerou o efeito simbólico e indireto de abonar a política de encarceramento em massa, o que é representado não só pelo discurso das leis penais aprovadas após a decisão pelo Congresso Nacional, mas também por algumas decisões importantes do próprio Supremo no período posterior, a despeito de algumas exceções importantes nesse caso.

A ausência de monitoramento judicial por parte do Supremo contribuiu, igualmente, para que a única medida possivelmente tida como estrutural - a vedação do contingenciamento das verbas do FUNPEN - se mantivesse inócua, não alterando em nada as ações públicas, nem os seus resultados práticos. De 2016 para cá, os investimentos públicos no sistema prisional foram consideráveis apenas em 2017, logo após a decisão do STF, tendo drástica queda nos anos seguintes. Os gastos com medidas alternativas para os presos tiveram também o seu ápice no orçamento de 2017, sendo praticamente reduzidas a zero nos anos 
posteriores. Ao lado disso, o número de presos continuou crescendo ao longo desses anos, inclusive, com a expansão do número de encarcerados em regime fechado.

Diante do exposto, se conclui que a ADPF 347 MC pode ter sido um primeiro passo na construção de uma jurisprudência mais atenta à situação caótica das penitenciárias brasileiras. No entanto, os efeitos da decisão não vão além disso, cuja causa principal o trabalho atribui à ausência de adoção de medidas dialógicas pela Corte, nomeadamente, a ausência de remédios judiciais dialógicos pelo Supremo, os quais permitiriam que o debate público não se esvaísse logo após a decisão, bem como a abstenção da Corte em exercer o monitoramento da efetivação da decisão, o que tornou a própria decisão liminar, na extensão em que deferiu os pedidos, inócua, em grande parte. Com isso, torna-se urgente que o STF revisite o tema, julgando o mérito da ação de modo a enfrentar essas questões, sob pena de coadunar com o cenário desumano do sistema prisional brasileiro.

\section{REFERÊNCIAS BIBLIOGRÁFICAS}

ARIZA, Libardo José. The economic and social rights of prisoners and constitutional court intervention in the penitentiary system in Colombia. In: MALDONADO, Daniel Bonilla (Eds.). Constitutionalism of the Global South: the activist tribunals of India, South Africa, and Colombia. Cambridge University Press: Cambridge, 2013.

AUGUSTO, Otávio. Cruz Vermelha critica combate à pandemia no sistema prisional do país. Metrópoles, 2021. Disponível em: <https://www.metropoles.com/brasil/cruzvermelha-critica-combate-a-pandemia-nosistema-prisional-do-pais>, acesso em 24 de mar. de 2021.

AVRITZER, Leonardo. O novo constitucionalismo latino-americano: uma abordagem política. In: AVRITZER, Leonardo et al (Org.). O constitucionalismo democrático latinoamericano em debate: soberania, separação de poderes e sistema de direitos. Belo Horizonte: Autêntica, 2017.
BARROSO, Neoconstitucionalismo e constitucionalização do Direito (o triunfo tardio do Direito Constitucional no Brasil). THEMIS - Revista da Escola Superior da Magistratura do Estado do Ceará, v. 4, n. 2, jul./dez.2006, p. 13-100.

BARROSO, Luís Roberto. O controle de constitucionalidade no direito brasileiro: exposição sistemática da doutrina e análise crítica da jurisprudência. $6^{\mathrm{a}}$ ed. rev. e atual. São Paulo: Saraiva, 2012.

BICKEL, Alexander. The least dangerous branch: The Supreme Court at the bar of politics. 2nd edition. Binghamton: BobbsMerrill Company Inc., 1986.

BRASIL. Departamento Penitenciário Nacional. Levantamento Nacional de Informações Penitenciárias - INFOPEN, dezembro/2016. Disponível em: <http://antigo.depen.gov.br/DEPEN/depen/ sisdepen/infopen>, acesso em 24 de mar. de 2020.

BRASIL. Departamento Penitenciário Nacional. Levantamento Nacional de 
Informações Penitenciárias - INFOPEN, dezembro/2017. Disponível em: <http://antigo.depen.gov.br/DEPEN/depen/ sisdepen/infopen>, acesso em 24 de mar. de 2020 .

BRASIL. Departamento Penitenciário Nacional. Levantamento Nacional de Informações Penitenciárias - INFOPEN, dezembro/2019. Disponível em: $<$ http://antigo.depen.gov.br/DEPEN/depen/ sisdepen/infopen>, acesso em 24 de mar. de 2020.

BRASIL. Lei n. 13.257/16, de 8 de março de 2016. Disponível em: <http://www.planalto.gov.br/ccivil_03/_At o2015-2018/2016/Lei/L13257.htm>, acesso em 24 de mar. de 2021.

BRASIL. Lei n. 13.769/18, de 19 de dezembro de 2018. Disponível em: <http://www.planalto.gov.br/ccivil_03/_At o2015-2018/2018/Lei/L13769.htm>, acesso em 24 de mar. de 2021.

BRASIL. Lei n. 13.869/19, de 5 de setembro de 2019. Disponível em: $<$ http://www.planalto.gov.br/ccivil_03/_at o2019-2022/2019/lei/L13869.htm>, acesso em 24 de mar. de 2021.

BRASIL. Lei n. 13.964/19, de 5 de setembro de 2019. Disponível em: <http://www.planalto.gov.br/ccivil_03/_At o2019-2022/2019/Lei/L13964.htm>, acesso em 24 de mar. de 2021.

BRASIL. Supremo Tribunal Federal (STF). Ação Declaratória de Constitucionalidade 43. Relator(a): Min. Marco Aurelio, Tribunal Pleno, Brasília, j. 07.11.2019, DJe 12.11.2020.

BRASIL, Supremo Tribunal Federal (STF). Ação Direta de Inconstitucionalidade 6299 Medida Cautelar. Relator: Min. Luiz Fux, decisão monocrática, Brasília, j. 15.01.2020, DJe 03.02.2020.
BRASIL. Supremo Tribunal Federal (STF). Arguição de Descumprimento de Preceito Fundamental 347 Medida Cautelar. Relator(a): Min. Marco Aurelio, Tribunal Pleno, Brasília, j. 09/09/2015, DJe 19.02.2016.

BRASIL, Supremo Tribunal Federal (STF). Habeas Corpus 143.641. Relator: Min. Ricardo Lewandoswki, $2^{\mathrm{a}}$ Turma, Brasília, j. 20.02.2018, DJe 09.10.2018.

BRASIL, Supremo Tribunal Federal (STF). Habeas Corpus 188.820 Medida Cautelar - Referendo. Relator: Min. Edson Fachin, $2^{\text {a }}$ Turma, Brasília, j. 24.02.2021, DJe 24.03.2021.

CONTROLADORIA-GERAL

DA UNIÃO. Portal da Transparência. Fundo Penitenciário Nacional - FUNPEN. Disponível em: $<$ http://www.portaltransparencia.gov.br/or gaos/30907?ano=2017 >, acesso em 24 de mar. de 2021.

COLÔMBIA. Corte Constitucional Colombiana (CCC). Sentencia SU1150/00. Magistrado Ponente: Dr. Eduardo Cifuentes Muñoz, Sala Plena de la Corte Constitucional Colombiana. Disponível em:

https://www.corteconstitucional.gov.co/rel atoria/2000/SU1150-00.htm. Bogotá, D. C., j. em 30-08-2000.

COLÔMBIA. Corte Constitucional Colombiana (CCC). Sentencia T-153/98. Magistrado Ponente: Dr. Eduardo Cifuentes Muñoz, Sala Tercera de Revisión, Corte Constitucional Colombiana. Disponível em: http://www.corteconstitucional.gov.co/relat oria/1998/t-153-98.htm . Bogotá, D. C., j. em 28-04-1998.

COLÔMBIA. Corte Constitucional Colombiana (CCC). Sentencia T-025/04. Magistrado Ponente: Dr. Manuel José Cepeda Espinosa, Sala Tercera de Revisón, Corte Constitucional Colombiana. 
Disponível

em:

http://www.corteconstitucional.gov.co/relat oria/2004/t-025-04.htm. Bogotá, D. C., j. em 22-01-2004.

COLÔMBIA. Congreso de Colombia. Ley n. 975 de 2005, Diario Oficial No. 45.980 de 25 de julio de 2005. Disponível em: < https://www.cejil.org/sites/default/files/ley _975_de_2005_0.pdf>, acesso em 05 de jan. de 2021.

COLÔMBIA. Ley n. 1448 de 2011, Diario Oficial No. 48.096 de 10 de junio de 2011. Disponível em:

https://www.mineducacion.gov.co/1759/w 3-article-

381583.html?_noredirect=1\#: :text=Por\% 201a\%20cual\%20se\%20dictan,y\%20se\%20 dictan\%20otras\%20disposiciones. $>$, acesso em 05 de jan. de 2021.

DAHL, Robert. Tomada de decisões em uma democracia: a Suprema Corte como entidade formuladora de políticas nacionais. Revista de Direito Administrativo. v. 252, 2009, pág. 25 a 43.

DÍAZ, Omar Huertas et al. El Estado de Cosas Inconstitucional um mecanismo de exigibilidade y garantia de los derechos humanos em Colombia y su aplicación em Brasil por la Corte Suprema. Revista DIREITO UFMS, Campo Grande, MS, v.3, n.1, p. 33 - 51, jan./jul. 2017.

GARGARELLA, Roberto. Constitution making in the context of plural societies: the "accumulation strategy". In: Constituent assemblies. ESLTER, Jon. GARGARELLA, Roberto. NARESH, Vatsal. RASCH, Bjorn Erik (Orgs). Cambridge University Press, 2018.

GARGARELLA, Roberto. El nuevo constitucionalismo dialógico, frente al sistema de los frenos y contrapesos. Revista Argentina de Teoría Jurídica, Volumen 14, Diciembre de 2013.
GLEZER, Rubens. MACHADO, Eloísa. Decide, mas não muda: STF e o estado de coisas inconstitucional. JOTA, 2015. Disponível em:

https://www.jota.info/opiniao-eanalise/artigos/decide-mas-nao-muda-stf-eo-estado-de-coisas-inconstitucional09092015, acesso em 18 de mar. de 2021.

HABERMAS, Jürgen. Direito e democracia: entre facticidade e validade. Volume I. $2^{\text {a }}$ ed. revista pela nova gramática da língua portuguesa. Rio de Janeiro: Tempo Brasileiro, 2012.

HIRSCHL, Ran. Towards juristocracy: the origins and the consequences of the new constitutionalism. Cambridge: Harvard University Press: 2007.

HOGG, Peter W. BUSHELL, Alisson. The Charter Dialogue between Courts and Legislatures (Or Perhaps the Charter of Rights isn't such a bad thing after all). Osgoode Hall Law Journal, Volume 35, Number 1 (1997), p. 75-124.

HOGG, Peter W. THORNTON, Allison A. Bushell; and WRIGHT, Wade K.. "Charter Dialogue Revisited: Or "Much Ado About Metaphors"." Osgoode Hall Law Journal, Volume 45, Number 1 (2007), p. 1-65.

HOLMES, Richard. SUNSTEIN, Cass R. The cost of rights: why liberty depends on taxes. New York: W. W. Norton \& Company, 1999.

JORNAL Brasil Atual Edição da Tarde 19 de março de 2021. Brasil de Fato, 2021. Disponível em: <https://www.brasildefato.com.br/2021/03/ 19/jornal-brasil-atual-edicao-da-tarde-19de-marco-de-2021>, acesso em 24 de mar. de 2021 .

KELSEN, Hans. Quem deve ser o guardião da constituição? In: Jurisdição constitucional. São Paulo: Martins Fontes, 2007. 
KYRITSIS, Dimitrios. A new interpretivist conception of the rule of law. Problema: Anuario de Filosofía y Teoría del Derecho, núm. 10, enero-diciembre, 2016, pp. 91-109.

KYRITSIS, Dimitrios. Justifying constitutional review in the legitimacy register. Journal for Constitutional Theory and Philosophy of Law Revus [Online], in print. April 2020. URL: <http://journals.openedition.org/revus/570 6>. Acesso em 29.04.2020.

MADISON, Alexander. The Federalist. Philadelphia: J. B. Lippincott \& Co., 1864.

MAGALHÃES, Breno Baía. A incrível doutrina de um caso só: análise do Estado de Coisas Inconstitucional na ADPF 347. Revista Eletrônica do Curso de Direito da UFSM, Santa Maria, RS, v. 14, n. 3, 2019, p. 1-37.

MAGALHÃES, Breno Baía. O Estado de Coisas Inconstitucional na ADPF 347 e a sedução do Direito: o impacto da medida cautelar e a resposta dos poderes políticos. Revista Direito GV, v. 15, n. 2, 2019, p. 1-37.

MARANIELLO, Patrício Alejandro. El activismo judicial, una herramienta de protección constitucional In: Pensar en derecho. Eudeba Universidad de Buenos Aires. Nro 1, Año 1, 2012, pág. 121 a 165.

MARIANO, Cynara Monteiro. FURTADO, Emmanuel Teófilo. MAIA, Isabelly Cysne Augusto. Contribuições do estado de coisas inconstitucional para a superação das omissões não normativas: dos entraves institucionais ao desenvolvimento humano. Revista Culturas Jurídicas, Vol. 5, Núm. 10, jan./abr., 2018, p. 182-205.

MENDES, Conrado Hübner. Direitos fundamentais, separação de poderes e deliberação. São Paulo: Saraiva, 2011.
MENDES, Conrado Hübner. Eu faço uma aposta com Fux. Folha de São Paulo, 2020. Disponível em: $<$ https://www1.folha.uol.com.br/colunas/c onrado-hubner-mendes/2020/09/eu-facouma-aposta-com-fux.shtml>, acesso em 24 de mar. de 2021.

MONTESQUIEU, Charles de Secondat, Baron de. O espírito das leis: as formas de governo, a divisão dos poderes. $9^{a}$ ed. São Paulo: Saraiva, 2008.

RAWLS, John. Political liberalism. Expanded edition. New York: Columbia University Press, 2005.

RIBEIRO, Djamila. O colapso no sistema carcerário no Brasil já é atual e tende a se aprofundar. Folha de São Paulo, 2020. Disponível em <https://www1.folha.uol.com.br/colunas/dj amila-ribeiro/2020/10/o-colapso-nosistema-carcerario-no-brasil-ja-e-atual-etende-a-seaprofundar.shtml?origin=folha\#>, acesso em 24 de mar. de 2021.

ROACH, Kent. Dialogic judicial review and its critics. Supreme Court Law Review, vol. 23, 2004, p. 49-105.

RODRÍGUEZ-GARAVITO, César. Beyond the courtroom: the impact of judicial activism on socioeconomic rights in Latin America. Texas Law Review, vol. 89(7), 2011, pp. 1669-1698.

RODRÍGUEZ-GARAVITO, César. RODRÍGUEZ-FRANCO, Diana. Juicio a la exclusión. El impacto de los tribunales sobre los derechos sociales en el Sur Global. $1^{\text {a }}$ ed. Buenos Aires: Siglo Venintiuno Editores, 2015.

RODRÍGUEZ-RAGA, Juan Carlos. Strategic deference in the Colombian Constitutional Court, 1992-2006. In: HELMKE, Gretchen. RÍOS FIGUEROA, Julio (Org.). Courts in Latin America. 
New York: Cambridge University Press, 2011.

SCHMITT, Carl. Constitutional theory. Durham and London: Duke University Press, 2008.

SMEND, Rudolf. Constitución y derecho constitucional. Centro de Estudios Constitucionales: Madrid, 1986.

STF volta a proibir prisão em $2^{a}$ instância; placar foi 6 a 5. Migalhas, 2019. Disponível em: < https://www.migalhas.com.br/quentes/314 723/stf-volta-a-proibir-prisao-em-2-instancia--placar-foi-6-a-5>, acesso em 24 de mar. de 2021.

SUNSTEIN, Cass R. A constituição parcial. Belo Horizonte: Del Rey, 2008.

STRECK, Lenio Luiz. Estado de Coisas Inconstitucional é uma nova forma de ativismo. Conjur, 2015. Disponível em: $<$ ht-tps://www.conjur.com.br/2015-out- 24/observatorio-constitucional-estadocoisas-inconstitucional-forma-ativismo> . Acesso em: 05 de jan. de 2021.

TASSINARI, Clarissa. Jurisdição e ativismo judicial: limites da atuação do judiciário. Porto Alegre: Livraria do Advogado Editora, 2013.

VILE, M. J. C. Constitutionalism and the separation of powers. 2nd ed. Indianapolis: Liberty Fund, 1998.

WALDRON, Jeremy. The core of the case against judicial review. Yale Law Journal, Volume 115, Issue 6, 2006, p. 1346 a 1406.

YEPES, Rodrigo Uprimny. Judicialization of politics in Colombia: cases, merits and risks. Sur - Revista Internacional de Direitos Humanos, São Paulo, n. 6, 2007, p. 53-69.

\section{THE STATE OF UNCONSTITUTIONAL AFFAIRS AS A STRATEGY OF INSTITUTIONAL DIALOGUE IN THE TRIAL OF THE ADPF 347 MC/DF BY THE FEDERAL SUPREME COURT OF BRAZIL}

Martin Magnus Petiz

How to cite this article: PETIZ, Martin Magnus. O Estado de Coisas Insconstitucional como estratégia de diálogo institucional no julgamento da ADPF $347 \mathrm{MC} / \mathrm{DF}$ pelo Supremo Tribunal Federal. Revista de Ciências do Estado. Belo Horizonte: v. 6, n. 1, e26989. ISSN: 2525-8036.

Abstract: The paper analyzes the capacity of the State of Unconstitutional Affairs (USoA) to serve as a strategy of institutional dialogue in the Federal Supreme Court of Brazil in litigation trials in which it is necessary to mobilize several actors to achieve a constitutional goal. To this end, the work has the normative aspect of developing the institutional dialogue as a model of separation of powers, a structure in which the branches interact with each other in the search for the best constitutional sense, which would have an epistemic potential to suppress unconstitutional omissions. In a second moment, the ECI will be presented as a decision-making technique, through bibliographic review and qualitative jurisprudential analysis of the paradigmatic judgments of the Colombian Constitutional Court, seeking to present analytical arguments on the possibilities and limits of the institute within the separation of powers structure presented, to, then, analyze how the STF proceeded in the 
ADPF 347 MC. The work concludes that the ideal application of the ECI, with greater effectiveness in both a material and symbolic sense, takes place through a decision involving its tracking by the Court, with the participation of social and political actors in the formulation of public policies, which has not been effected until now in ADPF 347, urging that the Supreme Court immediately revisit the issue in a final judgment.

Keywords: Unconstitutional State of Affairs; constitutional jurisdiction; separation of powers; institutional dialogue; ADPF 347 MC. 